\title{
Die teoloog as sendeling - Op soek na 'n sleutel vir Calvyn se sendingbeskouing
}

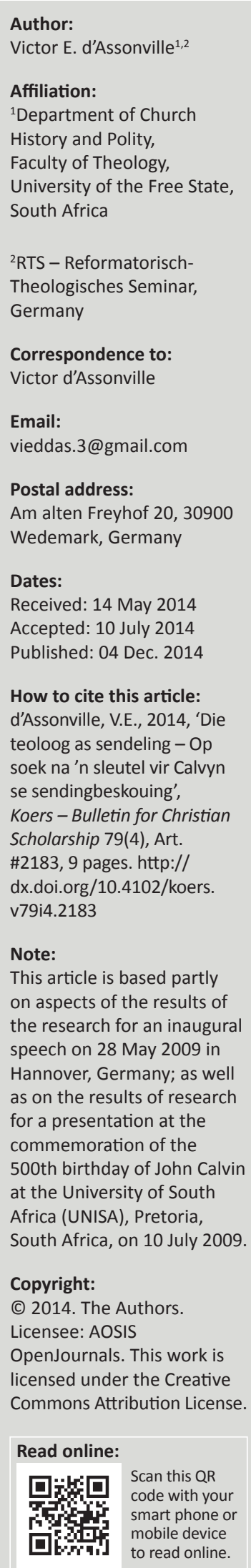

Die teoloog as sendeling - Op soek na 'n sleutel vir Calvyn se sendingbeskouing. Die bewering dat die Reformatore en by name Calvyn weinig of geensins in sending geïnteresseerd was nie, is nie nuut in die kerkgeskiedskrywing nie. Ten spyte van vele studies wat deur die loop van jare die teendeel aangetoon het, kom hierdie bewering ongekwalifiseerd steeds per geleentheid voor, byvoorbeeld in 'n resente publikasie van een van die wêreld se toonaangewende kerkhistorici. Juis ná afloop van die internasionale herdenkings van Calvyn se 500e geboortejaar in 2009 en die talle studies en publikasies wat daaruit voortgespruit het, is dit gepas om die vraag op 'n ander manier te belig: Watter teologiese grondmotiewe is belangrik in die sendingbeskouing van Calvyn? Die artikel stel die vraag oor die verhouding tussen sending en Calvyn aan die orde met spesifieke verwysing na die begrip sending, maar ook ten opsigte van sommige ander teologiese vrae. Volgens Calvyn het alle gelowiges 'n verantwoordelikheid in die uitdra van die evangelie. Die adressate van hierdie 'sendingwerk' is alle volke, alle mense, die hele wêreld. Hy bind die sendingtaak ekklesiologies in: vir hom is die kerk (die plaaslike gemeente) slegs kerk, wanneer dit missionêr georiënteerd is.

The contention that the Reformers, and especially Calvin, had little or no interest in mission is not new in church historiography. While many studies, conducted over years, have demonstrated the contrary, this groundless allegation continues to assert itself from time to time, for example as found in a recent best-seller by one of the world's leading church historians. Given that 2009 marked the world-wide commemoration of Calvin's birthday 500 years ago with the consequence of many studies published, it is appropriate to elucidate the question in a different manner: What theological motives are important in Calvin's view of mission? This article examines the issue of the relationship between mission and Calvin with regard to the concept of mission, but also concerning some other theological questions. According to Calvin, every believer has a role to fulfill in evangelism. The 'mission field' is comprised of every nation, all peoples, the entire world. Calvin interprets the task of mission ecclesiologically: for him the church (as local congregation) is only church when it has a missionary orientation.

\section{Inleiding}

Wanneer Johannes Calvyn in die herfs van 1539 in die stad Straatsburg sy kommentaar op die Romeinebrief afsluit (COR II/XIII; vgl. Parker \& Parker 1999, XI), ${ }^{1}$ sê hy met sy heel laaste sin: ${ }^{2}$

Die doel van die verkondiging van die evangelie ... vermeld hy [Paulus] weer, naamlik sodat God al die heidene [volke] byeenbring in gehoorsaamheid van die geloof. (COR II/XIII 317, 14-16) ${ }^{3}$

In hierdie sleuteluitspraak waarin die kern van die hele kommentaar in 'n sekere sin saamtrek, hoor ons ' $n$ uitspraak oor 'al die volke [= heidense volke] wat tot gehoorsaamheid in die geloof' gelei moet word. Maar die jong Calvyn, in sy 30e lewensjaar, deel met die laaste woorde van sy eerste Bybelkommentaar nie net die omvattende doel van die apostel Paulus se bediening mee nie. Implisiet gee hy ook ' $n$ aanduiding van sy eie persoonlike roeping. Hy sien homself immers as 'n geroepe dienaar van God soos hy dit 'n kwarteeu later in sy testament op sy sterfbed sou sê (CO 20, 299), ${ }^{4}$ naamlik as iemand wat oortuig was van sy roeping om die Woord van God uit te lê en te verkondig. ${ }^{5}$

\footnotetext{
1.Vgl. Parker \& Parker, 1999, Xi (in COR Iil/Xiii).
}

2.Op 18 Oktober 1539 het hy sy voorwoord tot sy Romeinekommentaar geskryf, waarin hy dit aan Grynaeus opdra, vgl. COR II/XIII, 6, 14f. 3.Afrikaanse vertaling deur S. Postma (Calvyn [1556] 2008:367).

4.CO 20, 299 (in sy testament): 'le, lean Calvin, Ministre de la parole de Dieu en l'Eglise de Geneve, ...

5.CO 20,299: 'le proteste aussi que i'ay tasché, selon la mesure de grace qu'il m'avoit donne, d'enseigner purement sa Parole, tant en sermons que par escrit, et d'exposer fidelement l'Escriture saincte. 
Soos kenmerkend vir Calvyn se metode van Skrifuitleg, is hierdie laaste sin van sy Romeinekommentaar sterk aan die betrokke Bybelteks gebonde, selfs wat die formulering betref. Daarom verwys Calvyn ook na Romeine 1:5 waar Paulus onder leiding van die Gees die 'Seun van God' vermeld, 'deur wie ons genade en die apostelskap ontvang het om geloofsgehoorsaamheid te verkry onder al die heidene ter wille van sy Naam' (COR II/XIII, 17, 17-36).

Dat dit in Romeine 1:5 en 16:26 (aan die begin en die einde van die Romeinebrief) oor sowel die apostoliese taak (die taak van 'n uitgestuurde, 'n gesant, 'n sendeling) asook oor alle volke (1933/1953-Afrikaanse vertaling: 'heidene') gaan as diegene wat die boodskap moet ontvang (die adressate), is voor die hand liggend. Met ander woorde, die wêreld is die teikengebied van hierdie sendinghandeling. Hier tree die apostel Paulus as teoloog maar ook as sendeling na vore (vgl. Barrett 1991). Vir Calvyn gaan dit hier egter nie om Paulus se gesag as teoloog nie. Dit gaan vir hom in die eerste en laaste instansie daaroor dat ons, net soos die gemeente in Rome byna 2000 jaar gelede en soos die gemeente in Straatsburg ... en Genève ... en die kerk oor die hele wêreld, met die doctrina Christi gekonfronteer word, met die Woord van God (vgl. d'Assonville 2001:201-202). Van daardie Woord was Paulus 'n apostel, 'n boodskapper ('n Bote Jesu vgl. Schlatter 1934). Om daardie Woord te verkondig, was Calvyn as dienaar beroep.

\section{Die moderne sendinggeskiedskrywing - 'n Eeu van kritiek}

Twee aspekte is opvallend wanneer die vraag oor sending by Calvyn ondersoek word. Eerstens is die lys van artikels oor hierdie onderwerp en onderwerpe wat daarmee verband hou lank; dit blyk byvoorbeeld uit Beeke (2004), Park (2009:124-127) en Schirrmacher (2009). 'n Blote soektog op die internet en in biblioteekkatalogusse wys op die omvang van artikels asook meer omvattende studies wat die afgelope jare hieroor verskyn het. Hieronder tel etlike proefskrifte, byvoorbeeld die Oxford-proefskrif van die Anglikaanse Calvynnavorser, Pete Wilcox. ${ }^{6}$ Sowel in die Engelssprekende as in die Duitssprekende, Nederlandse en ook Koreaanse wêreld vind 'n mens Calvynstudies oor hierdie onderwerp. Tog en miskien juis desnieteenstaande, is die tweede opvallende saak soveel te meer eienaardig, naamlik dat hierdie studies in die algemene kerkgeskiedskrywing om die een of ander rede nog nie omvattend neerslag gevind het nie. Tevergeefs soek 'n mens in die resente omvattende sendinghistoriografie na 'n diepgaande hantering van Calvyn se betekenis

6.Volgens 'n katalogussoektog het minstens drie Anglo-Amerikaanse proefskrifte wat hierdie problematiek aanraak in die twintigste eeu die lig gesien: Wilcox (1993) verskaf aan my deur die goedgunstige hulp van Wilcox - VEd'A.

Clark, Wm 1928 . The Conception of the Mission of the Church in Early Clark, Wm. 1928. The Conception of the Mission of the Church in Early Reformed Theology with special reference to Calvin's Theology and Practice in wissertation, New College, Edinburgh.) (A 1990:15).

Stevens, C.D. 1992. Calvin's corporate idea of mission. (Ph.D. Diss., Westminster Theological Seminary.) (Vgl. katalogus van Westminster Theological Seminary se biblioteek) vir die sendinggeskiedenis. By vele studies word hoogstens veralgemenend na 'n sogenaamde gebrek aan sendinggeoriënteerde denke by die Kerkhervormers verwys, hetsy by Luther of Calvyn. ${ }^{7}$

Tot 'n groot mate is die standaardwerk, Abriß einer Geschichte der protestantischen Missionen (tien uitgawes tussen 1882 en 1910) deur die beroemde sendingwetenskaplike, Gustav Warneck, grondliggend vir laasgenoemde gedagte. Die skaduwee hiervan val nog op die hantering van hierdie onderwerp tot in die een-en-twintigste eeu. In die inleidende sin van die gedeelte waar Warneck (1901:8) die sendingbewustheid en -bemoeienis tydens die sestiendeeeuse Reformasie behandel, oordeel hy ondubbelsinnig: 'Wie ... stand es in der jungen protestantischen Kirche? Trotz des Entdeckungszeitalters, in welches ihre Entstehung fällt, fehlt ihr im Zeitalter der Reformation die Missionst[h]at.'

Terwyl Warneck (1901) wel begrip probeer toon vir die uitsonderlike situasie waarin die Reformatore hulle bevind het, kom hy later tot 'n nog skerper beoordeling:

Nicht bloß die Missionst[h]at, sondern selbst den Missionsgedanken in dem Sinne, wie wir ihn heute verstehen, vermissen wir bei den Reformatoren ... weil theologische Grundanschauungen sie daran hinderten, ihrer $\mathrm{T}[\mathrm{h}]$ ätigkeit und selbst ihrem Gedanken eine Missionsrichtung zu geben. (bl. 9)

Ná besprekings van Luther, Melanchthon, Bucer en Zwingli, vel hy in dieselfde lyn van argumentasie ook 'n oordeel oor Calvyn se sendingbewustheid: '... von der Anerkennung einer solchen Pflicht (sendingplig deur die gemeente - VEd'A) findet sich auch bei Calvin nichts' (Warneck 1901:20). Volgens Warneck was Calvyn se mening daartoe beperk dat slegs (nur) die Christelike owerheid die verantwoordelikheid gehad het om die 'ware godsdiens' in 'n land wat nog ongelowig is, in te voer (ibid:20). Hy gaan, ná aanhalings van Calvyn, selfs sover om tot die volgende slotsom te kom:

Daraus folgt auch für ihn (Calvin - VEd'A) von selbst, daß es einer besonderen Veranstaltung zur Ausbreitung des Christentums unter nichtchristlichen Völkern, d.h. der Mission (beklemtoning VEd'A) nicht bedarf. (Warneck 1901:20)

Dat hierdie standpunt deur die verdere verloop van die twintigste eeu algemene byval sou vind en dit sou behou, blyk nie net uit S. Neill se werk, A history of Christian missions (1964), nie (vgl. Wilcox 1995:201), maar ook uit die gesaghebbende Oxford Dictionary of the Christian Church: 'With the Reformation missionary enterprise slackened, particularly in the Reformed Churches ...' (Anon. 1957:907908). ${ }^{8}$

7.'n Uitsondering op die reël blyk die Biographical Dictionary of Christian Missions onder redaksie van Gerald H. Anderson (1997, met' $n$ sagtebanduitgawe in 1999) is meer ewewigtis en gedifferensieerd.

8.Dieselfde bydrae oor sending met dieselfde uitspraak is in latere uitgawes van die Oxford Dictionary of the Christian Church herhaal, byvoorbeeld die tweede uitgawe van 1974 (Anon. 1974:923) sowel as die derde uitgawe van 1997 (Anon. 1997:1101). 
Ook in resente sendingwetenskaplike navorsing vind 'n mens soortgelyke onbegronde uitsprake, byvoorbeeld dié van Mereweather-Thompson (2010):

The Reformation, preoccupied with changing the state of the Catholic Church, seemed to have diverted energy from such mission and dialogue as had been the focus of the Lateran Councils (1123-1517). The emphasis now was on radical change, a trend which the Roman Catholic Church tried hard to resist. One after the other, the Reformers - Luther, Calvin and Zwingli - defended the doctrinal positions to which they were committed but gave little attention to mission and dialogue as we know them. That was to wait - where mission is concerned - until the time of the Wesleys in England in the eighteenth century, and - where dialogue is concerned until much later in nineteenth century with the start of the Ecumenical Councils. (bl. 49)

Dat daar in 'n proefskrif só ' $n$ bewering oor die Reformatore gemaak word, is teen die agtergrond van Warneck en die twintigste-eeuse kerk- en sendinggeskiedskrywing miskien nie verrassend nie. Dat dit egter sonder meer sonder enige bron- of literatuurverwysing gedoen word, is wel vreemd en bevestig hoe maklik daar in teologiese refleksie met clichés en eensydighede, veral oor die Reformasie, volstaan word.

Wat sake verder kompliseer, is die feit dat die sendingtema in elk geval, veral in die Westerse wêreld en in die besonder in Europa, 'n gekompliseerde, belaste en deesdae ook negatiefgekleurde onderwerp is. Ter illustrasie hiervan kan bloot na die inleidende sin oor die onderwerp sending (Mission) in die Wörterbuch des Christentums verwys word:

Die christelike sendingwerksaamheid word deesdae nie slegs deur nie-Christene afgewys nie, maar roep ook by sommige Christene twyfel na vore, wat in 'n sekere sin deur die nuwetydse sendinggeskiedenis self veroorsaak is. (Kollbrunner 1988:811) ${ }^{9}$

Meer as 'n eeu ná bogenoemde publikasie van Warneck het sy stellings nog steeds nie aan veld ingeboet nie. Dít blyk uit 'n resente boek wat oor die laaste 500 jaar van die kerkgeskiedenis handel, naamlik dié van Alister McGrath (2008). In sy behandeling van die geskiedenis sedert die Reformasie tot die een-en-twintigste eeu herhaal McGrath die stellings van Warneck nie net instemmend nie, maar hy gaan boonop verder:

During its formative phase, Protestantism seems to have had little interest in the notions of 'mission' and 'evangelism'. Neither John Calvin nor Martin Luther had any particular concern to reach beyond the borders of Christendom ... (McGrath 2008:175)

Vir sy beoordeling beroep McGrath (2008) hom spesifiek op Warneck:

This early Protestant disinterest in mission was first noted by Gustav Warneck in the 1880's. ... Although his observations have been qualified by subsequent scholarship, they have yet to be convincingly rebutted. (bl. 175)

9.'Die christliche M.[ission]stätigkeit stößt heute nicht nur bei Nichtchristen auf Ablehnung, sondern ruft auch bei manchen Christen Bedenken hervor, die z.T. durch die neuzeitl.[iche] M.[ission]sgeschichte selber verursacht sind ...'

\section{Ander stemme ${ }^{10}$}

Dit is nie dat Warneck nooit akademies weerspreek is nie. Nog kort voordat die laaste van die tien uitgawes van Warneck se Abriß einer Geschichte der protestantischen Missionen in 1910 gepubliseer is, verskyn Schlatter (1909) se artikel wat Calvyn se sendingbeskouing opvallend anders as Warneck beoordeel. Hoewel Schlatter ook meen dat die daadwerklike oorgang tot 'n algemene kragtige oproep tot sending by Calvyn nog ontbreek, is sy teologiese analise tog heelwat meer genuanseerd as dié van Warneck (Schlatter 1909:340-342). Hy kom tot die slotsom dat die latere sterk sendingbewussyn in veral 'n beweging soos dié van die Piëtisme hoofsaaklik uit die voedingsbron van Calvyn se teologie voortgekom het (ibid:342, 343).

Presies 'n kwarteeu ná Schlatter se artikel publiseer Pfisterer (1934) ook 'n ander aanslag as Warneck in sy hantering van Calvyn se sendingbeskouing. In sy uitvoerige uiteensetting wat hoofsaaklik op die Institusie en kommentare van Calvyn gebaseer is, toon Pfisterer oortuigend aan watter plek die gedagte van sending (Missionsgedanke) by Calvyn binne die groter geheel van sy teologiese denke ingeneem het. Verskillende teologiese temas soos dit by Calvyn tot uitdrukking kom, word deur Pfisterer bespreek: heidense volke en antropologie (ibid:94-97), naasteliefde, antropologie en soteriologie (ibid:97-99), die uitverkiesing (ibid:99-100), gebed (ibid:100-101), die eer van God (ibid:101), ampsleer (ibid:102-103), ensovoorts. Sy uiteensetting bring hom tot 'n teenoorgestelde gevolgtrekking as Warneck:

So werden gerade durch die Erwählungslehre die Christen zur höchsten Aktivität aufgerufen, weil sie wissen, daß Angehörige aller Rassen und Völker, Länder und Staaten zur ewigen Seligkeit bestimmt sind. Daß man sich nicht hinter den Vorwand einer allgemeinen christlichen Zeugnispflicht verkriechen kann und darf, geht aus all dem Angeführten (aanhalings van Calvyn - VEd'A) klar hervor. (Pfisterer 1934:104)

Met verdere verwysings na onder meer die gereformeerde sendinginisiatief in Brasilië (vanaf 1556) en ander historiese gegewens binne hulle samehang met Calvyn se teologie, kan Pfisterer (1934:107) tot die slotsom kom: 'So ist der kalvinische Missionsgedanke aus der Zeitlage entstanden und weist doch weit über sie hinaus.'

Die besinning oor Calvyn se sendingdenke is egter nie tot die Duitssprekende wêreld beperk nie. In 1950 skryf die bekende Amerikaanse Islamkenner en voormalige sendeling onder Moslems, Samuel M. Zwemer, 'n omvattende artikel, 'Calvinism and the missionary enterprise', waarin dit in die eerste plek oor Calvyn en sy teologiese begronding vir sending as sodanig gaan. Met verwysings na verskillende

10. Met die Calvynjaar in 2009 het daar nogal 'n aantal publikasies oor hierdie onderwerp verskyn wat indirek ook Warneck McGrath en andere weerlê, onderwerp verle, byvoorbeeld Labuschagne (2009), Haykin (2009), Park (2009), Thomas (2009), Schirrmacher (2009 - met herpublikasie van vorige studies uit die twintigste eeu) en Morecraft (2010). In hierdie artikel word egter meer op die vraag gefokus waarom McGrath (2008) en andere met Warneck se tese volstaan, ten spyte van vroeere weerleggende studies in die twintigste eeu, asook aan die ander kan waarom in omvattende werke soos die Calvyn Handboek (Selderhuis 2008a, 2008 b, 2009) sending as onderwerp of tema nie afsonderlik behandel word nie. 
genres van Calvyn se werke, die Institusie en preke van hom, lewer Zwemer 'n pleidooi vir 'n herwaardering van Calvyn se oop oog vir sending. Hy bevind Calvyn 'arose above his age and above his contemporaries' (Zwemer 1950:211) en onderstreep hiermee Pfisterer se gevolgtrekkings. Hierby maak Zwemer ook weer melding van die sendingekspedisie na Brasilië in 1556, wat op versoek van Admiraal Gaspard de Coligny deur Calvyn en sy Geneefse kollegas ondersteun is en waaraan sendelinge vanuit Genève ook deelgeneem het (vgl. Manetsch 2008:512) - 'n onderneming wat Zwemer (ibid:211) noop om Calvyn as die enigste Reformator te beskryf wat by sodanige oorsese sendingprojek betrokke was. In die res van sy artikel gaan Zwemer (ibid:212-216) met positiewe waardering op die verdere historiese ontwikkeling van die tyd ná Calvyn in.

Dat Warneck 100 jaar gelede - teen die agtergrond van die negentiende-eeuse teologie - tot sy gevolgtrekkings kon kom, sou gedeeltelik kontekstueel verklaar kon word aan die hand daarvan dat die sendingwetenskap sowel as die sendinggeskiedenis as teologiese deelwetenskappe nog in hulle kinderskoene gestaan het. Trouens, Warneck het ' $n$ besondere rol in die vestiging van hierdie wetenskappe gespeel. Dat McGrath egter meer as 'n eeu later die Warneck-stellings onkrities oorneem en daaraan verdere populariteit verleen, ontlok nie sonder rede verbasing nie (vgl. McKay 2008:83 e.v.). Ná Warneck is daar heelwat Calvynstudies - ook omvattende studies (bv. Wilcox 1993) sowel in die Anglo-Amerikaanse (vgl. Van den Berg 1950, of die lys in Beeke 2004:68-69) as in kontinentale verband (bv. Schlatter en Pfisterer) wat tot ander bevindings as Warneck kom. McGrath laat egter nie blyk dat hy daarvan kennis geneem het nie (ofskoon hy as Oxford-professor en promotor van Wilcox uiteraard deeglik van laasgenoemde se bevindings bewus is). Hy (McGrath 2008:497) verwys slegs na 'n Finse studie deur Oberg (1991) oor Luther in hierdie verband ${ }^{11}$ en kom dan tot die volgende konklusie:

Although there is no doubt that the basic elements of a missionary theology can be found in the writings of both Luther and Calvin, they were like vestigial organs - present but not perceived to be useful. (bl. 498)

Buiten vir sy visie op die Reformatore en sy Calvynbeeld, reflekteer McGrath se onkritiese instemming met Warneck sy eie bepaalde sendingbeskouing in aansluiting by Warneck se siening van sending en sy gebruik van die sendingbegrip.

\section{Die begrip sending (missio) Missio in die klassieke teologie}

Die teologiese ontvouing van die begrip sending en sy oordragtelike gebruik sou eers relatief lank ná die sestiende eeu volg. Hiervolgens is die Latynse begrip missio (Mission, mission, sending of zending - afhangende van die taal) vir die verkondiging van die evangelie aan nie-Christene gebruik,

11.0berg, 1., 1991, Luther och världsmissionen, Abo Akademi; (vgl. McG Grath 2008:497) sodat hulle tot geloof in die God van die Skrifte kan kom. ${ }^{12}$ Hierdie gebruik laat wel ruimte vir die algemene sin waarin Gustav Warneck die begrip heidensending gebruik, wat dit egter nie daartoe beperk nie, maar as sodanig 'n breër veld dek.

Voordat daar egter by Calvyn se siening van sending stilgestaan kan word, moet in gedagte gehou word dat die begrip sending, spesifiek in sy Latynse oorsprong missio, as teologiese begrip ' $n$ bepaalde ontwikkeling deurgemaak het. Dogmaties word hierdie Latynse konsep in die klassieke teologie oor die Drie-eenheid gebruik om die binnetrinitariese sending van die Seun en die Gees onderskeidelik tot uitdrukking te bring. Missio Dei is hiervolgens die aanduiding van die goddelike 'Selfsending van die Seun en die Heilige Gees in die wêreld' (Barth 1932:204) - 'n begrip wat uit die Vroeë Kerk se leer oor die Drie-eenheid voortspruit. Daarom is missio Dei 'n sleutelbegrip in die teologie (Wentsel 1981:348, 349). ${ }^{13}$

Binne die hedendaagse teologiese denke oor sending word vanuit hierdie klassieke teologiese gebruik van missio Dei 'n begronding vir die sending aangevoer (Bosch 1979:78 e.v.; vgl. ook Wierda 2001:8 e.v.).

\section{Teologiese vraagstellings}

Aanvullend by die klassieke gebruik van die begrip missio was daar in die twintigste eeu in die dogmatiek sowel as in die sendingwetenskap 'n algemene besinning oor die verhouding tussen sending en teologie. Hierdie besinning en nadenke was veral 'n uitvloeisel van die ontwikkeling van die sendingwetenskap as teologiese wetenskap sedert die negentiende eeu (Vorgrimler 2000:419).

'n Goeie voorbeeld van só 'n diskussie was die een wat in die dertigerjare van die vorige eeu tussen Karl Barth en die sendingwetenskaplike Siegfried Knak plaasgevind het. Op die Brandenburgse Sendingkonferensie in Berlyn op 11 April 1932 lei Barth hierdie diskussie met sy voordrag, 'Die Theologie und die Mission in der Gegenwart', in. Ná die publikasie van hierdie voordrag in Zwischen den Zeiten reageer Knak (1932) in die volgende uitgawe van dieselfde tydskrif daarop. Veral die volgende vrae word in die diskussie hanteer (Knak 1932:332): ${ }^{14}$ Wat is sending?; Wat is teologie?; Wat is die gemeenskaplike skakel tussen sending en teologie en watter onderskeid is daar in die diens van albei onderskeidelik?; en Watter moontlike diens is daar wat die teologie aan die sending kan lewer?

12.0p die onderskeid tussen sending (Mission; Äßßere Mission; auswärtige Mission missio externa) en evangelisasie (Evangelisation; Innere Mission; Volksmission missio interna - sien Barth 1959 KD IV, 3, 2:999 e.v.) - word hier nie ingegaan nie.

13.Vergelyk Wentsel (1981:349): 'Missio Dei. God zendt zijn Zoon uit de hemel de wereld in (vgl. Jh 17). De Zoon zendt de apostelen de wereld in. In de apostelen is de gehele kerk inclusief begrepen ...' Vergelyk verder Barth (1959: KD IV, 3, 2:780 e.v.) Kollbrunner (1988:813). Van de Beek (2012:108-109) behandel ook die begrip Kollbrunner (1988:813). Van de Beek (2012:108-109) behandel ook die begrip teologies-histories, veral met verwysing na Moltmann, by wie hy vasstel: 'Hoewel hij de term 'missio Dei' slechts sporadisch gebruikt ... kan men het theologische
oeuvre van Jürgen Moltmann als de breedste uitwerking van deze gedachte zien ...'

14.Knak (1932:332): 'Was ist Mission? Was ist Theologie? Was gibt es gemeinsames zwischen ihnen und worin besteht die Verschiedenheit ihres Dienstes? Welchen menschenmöglichen Dienst also kann die Theologie der Mission leisten?' 
Daar is addisioneel tot hierdie vrae ook verdere NuweTestamentiese temas, byvoorbeeld die vraag oor die verhouding tussen Paulus as teoloog en as sendeling, of tussen Paulus en Petrus met verwysing na hulle sendingwerksaamheid. 'n Katalogussoektog toon aan hoe gereeld 'n onderwerp soos 'Paulus as teoloog en sendeling' (vgl. Barrett 1991) in die teologiese vakliteratuur oor die Nuwe Testament voorkom.

\section{Sending by Calvyn - Werklik 'n onbekende fenomeen?}

'n Onwaarskynlike verklaring vir McGrath, wat self in 1990 'n biografie oor Calvyn gepubliseer het, se volharding met Warneck se tese sou die volgende kon wees: daar is in die bekende en algemene navorsing nie genoegsaam navorsingsresultate beskikbaar oor Calvyn se sendingbenadering nie, of die feite en die navorsing is nie toeganklik nie. ' $\mathrm{n}$ Blik in die verskillende uitgawes van die Calvyn Handboek (Selderhuis 2008a, 2008b, 2009) toon egter dat daar wel verskillende verwysings na 'n sendinggeoriënteerde Calvyn gevind kan word. So lees 'n mens byvoorbeeld dat die jong Calvyn reeds in 1535 'n sendinggeskrif (Missionsschrift) opgestel het (Neuser 2008:29 e.v.; vgl. Neuser 2009:161, 167 e.v., 173 vir 'n meer uitvoerige behandeling van hierdie tema). Boonop word die brief waarin Calvyn sy Institusie aan Koning Francois I van Frankryk opdra (geskryf in 1535 en die eerste keer in 1536 sowel as in alle uitgawes daarna gepubliseer) onder meer as 'theologisch eine missionarische Ansprache' (beklemtoning - VEd'A) bestempel (Selderhuis 2008c:199). Verder word aangetoon hoe die Geneefse Akademie sendelinge opgelewer het (Naphy 2008:56) en hoe predikers as sendelinge na Frankryk gestuur is (Mentzer 2008:82). In sy 'literêre Joodse sendingwerk' het Calvyn ondersteuning van die Christelike Jood Immanuel Trimellius ontvang (Lange van Ravenswaay 2008:144), ${ }^{15}$ terwyl uit Calvyn se voorlesings oor Ou-Testamentiese boeke, veral oor die profetiese boeke, dit duidelik blyk watter sentrale plek die missiologiese aspek daarin ingeneem het: ${ }^{16}$ 'Calvins Erläuterung der Propheten gewährt auch einen Einblick in seine Behandlung apokalyptischer Themen und den missionarischen Schwerpunkt seiner Vorlesungen' (Blacketer 2008:187).

Daarenteen is dit opvallend dat ' $n$ mens in die Duitse weergawe van die Caloyn Handboek tevergeefs in sowel die inhoudsopgawe as die onderwerpsindeks na die tema Mission soek (vgl. Selderhuis 2008a). Dieselfde geld vir die Engelse weergawe daarvan (Selderhuis 2009). In die Nederlandse uitgawe van die Handboek is die begrip Zending darem in die onderwerpsregister (Register van zaken)

15.Immanuel Tremellius [war] für Calvin zu einem wichtigen Gesprächspartner geworden ..., zumal dieser ... Calvin so in seiner literarischen judenmissionarischen Arbeit unterstützte' (Lange van Ravenswaay 2008:144).

16.Die sendingtema kom origens ook by ' $\mathrm{n}$ aantal ander geleenthede in die Calvyn Handboek ter sprake. Dan egter is dit telkens binne die raamwerk van die 'Wirkungsgeschichte', waar in die navolging van en in aansluiting by die teologie van Calvyn latere geslagte gereformeerdes by sendingwerk betrokke was, byvoorbeeld in Afrika (Britz \& d'Assonville 2008:499-500, 504), in Asië (Ahn 2008:505-506, in Afrika (Britz \& d'Assonville 2008:499-500, 504), in Asië (A
$508-510$ ) of in Noord-Amerika (Manetsch 2008:512, 516-517). opgeneem (Selderhuis 2008b:649) - binne die konteks van die 'doorwerking en receptie van Calvijn'; maar in die bronen literatuurverwysings van die Calvyn Handboek (al die uitgawes) is slegs een verwysing na 'n publikasie wat primêr die sending as onderwerp hanteer, naamlik die artikel oor die geskiedenis van die sendinginisiatief na Brasilië van 1556 (in die literatuurlys van Selderhuis 2008a:526, 2008b:583, 2009:533). ${ }^{17}$

Die verwysings na sending by Calvyn, volgens die huidige stand van internasionale navorsing in die Calvyn Handboek, laat dus iets van 'n anomalie deurskemer. Aan die een kant is daar deurentyd die implisiete lyn van sending wat veronderstel word en direk met Calvyn se siening oor die uitbreiding van God se koninkryk en met die sentrale rol van Genève as opleidingsentrum vir sendelinge verband hou ook min of meer die belangrikste lyne van argumentasie in resente artikels oor Calvyn en die sending. Aan die ander kant is dit egter opvallend dat die gedagte of die tema van sending, met die aantal uitsonderings wat spesiale studies betref, as sodanig nie 'n primêre plek in die algemene teologiese en historiese beeld wat oor die Geneefse Hervormer en sy teologiese nalatenskap bestaan, inneem nie en ook nie as afsonderlike onderwerp in die Handboek behandel word nie.

\section{'n Anachronistiese vraagstelling?}

Die vraag wat hieruit spruit, is of navorsers soos Warneck en McGrath - albei op sigself in hulle tydvak (aan die begin van die twintigste en een-en-twintigste eeu onderskeidelik) taamlik verteenwoordigend vir die algemene teologieshistoriese navorsingsgemeenskap - op 'n adekwate wyse met Calvyn en sy werk in die relasie daarvan met sending omgegaan het. Het ons bykomend by hierdie vraag nie eerder met verskillende sendingbeskouings of verskillende gebruike van (die) sendingbegrip(-pe) te doen nie? Met ander woorde, bedoel die verskillende navorsers dieselfde met sending (Engels: mission; Duits: Mission of Heidenmission) ${ }^{18}$ Daar sou addisioneel egter ook gevra kon word of die teenstrydige beoordelings slegs met bepaalde historiese vraagstellings en ' $n$ bepaalde hantering van die sendingbegrip verband hou. Is daar nie dalk onderliggend ook van ander teologiese aspekte sprake nie? Dit het wel neerslag gevind in studies soos dié van Pfisterer (1934), Van den Berg (1950) asook onlangs in Labuschagne (2009) en tot 'n mate in Morecraft (2010).

Dat die sendingbegrip in sy huidige betekenis nie in die sestiende eeu gebruik is nie, is bekend. Hierby sluit die kritiese vrae wat Gensichen (1960) sowat 'n halwe eeu gelede al gestel het, op ' $n$ insiggewende wyse aan: ${ }^{19}$

Could it be that the modern form and structure of missionary activity was not the only possible norm for missions? Should

17. Die verwysing is na die artikel deur Beaver (1967) wat onderskeidelik deur Selderhuis (2008a:526, 2008b:583, 2009:533) aangehaal is.

18.Warneck (1901:10) definieer Heidenmission soos volg: '... eine geordnete Sendung von Boten des Evangelii zu den nicht-christlichen Völkern behufs ihrer Christianisierung ...'

19.Gensichen (c. 1960:119-127), 'Were the reformers indifferent to mission?' (in Dankbaar 1978; soos aangehaal deur Pogson 1990:15). 
not modern missionary conceptions and practices be examined in the light of the Reformation, rather than the attitude of the Reformers in the light of what had come to be considered as the only legitimate standard for missions? (Vgl. Pogson 1990:15)

In aansluiting by Gensichen (c. 1960) sou 'n mens verder kon gaan: Is die sendingtema of die negentiende- en twintigsteeeuse vraagstellings oor sending(-ywer) by die Reformatore in die sestiende eeu nie anachronisties en dus in sy wese ongeldig nie?

Meer dieperliggend is egter die vraag watter teologiese verklarings moontlik vir die teenstrydighede en die anomalieë in die sienings oor Calvyn se sendingbeskouing gevind kan word. Om weer by bogenoemde verwysings in die Calvyn Handboek aan te sluit: Is alles wat oor die tema, sending, by Calvyn belangrik is, dan reeds gesê of voldoende hanteer?

Met bogenoemde as agtergrond word kortliks na Calvyn se sendingbeskouing gekyk met verwysing na enkele Bybeltekste en verklarings daarvan. Weens die beperking van hierdie bydrae, kan die volle omvang daarvan nie hanteer word nie en word met die volgende opmerkings volstaan.

\section{Sendingopdrag net vir die apostels?}

Dit is opvallend dat die sogenaamde klassieke sendingtekste, byvoorbeeld Matteus 28:19 of Markus 16:15, in die diskussie waar die Warneck-kwalifikasie steeds op populêre vlak in die hoofstroom kerk- en sendinggeskiedskrywing gehandhaaf word, 'n sentrale plek inneem. McGrath (2008) se weergawe van Warneck se eerste rede vir 'Protestantism's lack of interest in missions' bied 'n illustrasie hiervan:

These early Protestants interpreted the 'Great Commission' - the command to 'go and make disciples of all nations' (Matthew 28:19) - as a task given to the apostles of the first century, not to their successors in the post-apostolic church. (bl. 176) ${ }^{20}$

Ook uit ander geledere is hierdie aantyging al gehoor. Die Anglikaanse biskop E.J. Palmer stel sy standpunt byvoorbeeld in 1927 by die Lausanne World Conference on Faith and Order (Conférence Mondiale de Lausanne):

Calvin made the most amazing mistake for an able man when he tried to reform the Church by reconstructing it after the pattern of the apostolic age minus the Apostles. The Spirit that has directed the history of the primitive Church was wiser than Calvin. (Vgl. Dankbaar 1978:185)

Die argument is dus dat Calvyn volgens Warneck en Palmer (asook McGrath in navolging van Warneck) daarvan beskuldig word dat hy die sendingopdrag van die 'klassieke tekste met die sendingbevel' (Matt 28:18-20 of Mark 16:15) primêr op die apostels betrek. Volgens die redenasie van hierdie historici, ontbreek die sendingbewussyn dus by Calvyn en ander tydgenote, aangesien hy nie 'n oop oog

20.Vergelyk Warneck (1901:10-20) waar hy Luther, Melanchthon, Zwingli en Calvyn agtereenvolgens behandel - dit word instemmend deur McGrath opgesom en weergegee. daarvoor gehad het dat die sendingopdrag ook vir die latere generasies geld nie.

Reeds meer as 60 jaar gelede het W.F. Dankbaar hierdie bewering oor Calvyn se siening van die apostelamp indringend ondersoek - 'n studie wat byna 30 jaar later weer gepubliseer is (Dankbaar 1978). Op grond van Calvyn se gedifferensieerde sig op die apostelamp en sy noukeurige erns waarmee hy met die Skrifteks omgegaan het, toon Dankbaar aan dat volgens Calvyn nie alle opdragte eenvoudig a-histories op die kerk van die tyd ná die apostels oorgedra word nie. In die geheel kom Dankbaar, in teenstelling met Warneck en Palmer, ${ }^{21}$ egter tot ' $n$ opvallend meer positiewe oordeel ten opsigte van Calvyn se sendinggesindheid in die geheel, maar ook ten opsigte van Calvyn se siening van die apostelamp in die besonder (Dankbaar 1978:197-199).

\section{Op weg na 'n meer gedifferensieerde perspektief}

Hierbo is reeds daarop gewys dat daar in die hantering van die sendingbegrip maar ook in die teologiese vraagstelling as sodanig verklarings vir die verskillende en dikwels teenstrydige oordele oor Calvyn se sendingbeskouing gevind kan word. Die verklarings vir hierdie anomalieë lê egter nie slegs op die vlak van begrippe en die vraagstelling of (nog meer algemeen) 'n kombinasie van albei nie, maar ook in die manier hoe Calvyn gelees word, hoe daar in die uitleg van sy skrifte met hom omgegaan word en - wat meer is - die insig wat daar in die manier is waarop Calvyn op sy beurt die Skrif gelees het. Dit is dus in 'n groot, selfs deurslaggewende opsig, 'n metodologiese (en ook hermeneutiese) kwessie: Hoe word Calvynnavorsing (of enige ander teologies-historiese navorsing) gedoen? Wat is die vrae wat aan die tekste gestel word? Hoe word daar met die verskillende genres omgegaan? Is daar 'n oop oog vir die geskiedkundige agtergrond wat 'n rol by die ontstaan van 'n teks gespeel het? ${ }^{22}$

Daar is verskillende moontlikhede om Calvyn se teologiese denke oor sending te benader, byvoorbeeld deur hoofteologiese lyne binne die konteks van al sy werk te ontleed, ${ }^{23}$ veral waar dit van ander mede-kerkhervormers onderskei word. Daar kan dus na Calvyn se Christologie, sy pneumatologie, sy Godsleer (teologie), sy eskatologie, sy ekklesiologie, ensovoorts gekyk word. Aan die ander kant sou hierdie analise ook op grond van die struktuur van sy Institusie of ander genres van sy geskrifte (bv. briewe, kommentare, voorlesings [praelectiones], traktate, kerkordes, ens.) gedoen kon word. In hierdie artikel word volstaan met opmerkings na aanleiding van die begrip sending en die sogenaamde sendingtekste.

21.Dankbaar $(1978: 185,186)$ vermeld sowel Warneck as Palmer, asook andere wat soortgelyke opinies as hulle huldig.

22.Vergelyk d'Assonville (2008:373) vir 'n kort uiteensetting van die verskillende aspekte wat metodologies belangrik vir Calvyn navorsing is.

23.Labuschagne (2009:2 e.v.) doen dit in aansluiting by David Bosch ten opsigte van die volgende aspekte: (1) The doctrine of justification; (2) the perspective of the essential sinfulness of man; (3) the subjective dimension of salvation; (4) the priesthood of all believers; and (5) the centrality of the Scriptures. 
Wanneer 'n mens Calvyn se uitleg van die klassieke sendingtekste lees (Matt 28:19; Mark 16:15), ${ }^{24}$ is etlike aspekte opvallend. Calvyn onderskei wel teologies baie deeglik en noukeurig tussen opdragte wat die historiese apostels kragtens hulle apostelamp ontvang het aan die een kant, en eise aan die kerk van alle tye aan die ander kant (vgl. Dankbaar 1978:185 e.v.). Hy trek die lyne van hierdie eksegeties-begronde onderskeidings veral konsekwent na sy ekklesiologie deur. Só kan hy by geleentheid van Matteus 28:19 ook van die gehoorsaamheid van die geloof praat (soos by Rom 1:5 en 16:26) en die opdrag 'gaan heen' primêr op die apostels van toepassing maak. Dit kan egter misgekyk word dat Calvyn onmiddellik die prediking, die verkondiging van die evangelie beklemtoon. Dit lei daartoe dat Calvyn die aanspraak van Rome, naamlik dat die pous in die direkte lyn van die apostels staan (die apostoliese suksessie) reeds bloot op grond van die ontbrekende Woordverkondiging in die Roomse Kerk kan afwys. Sodoende word die volgende duidelik: Terwyl dit aanvanklik mag lyk asof Calvyn in sy kommentaar by hierdie sendingteks die sendingopdrag uitsluitlik op die apostels toepas, ${ }^{25}$ hou hy twee lyne vas. Eerstens wys hy die Roomse aanspraak op die apostoliese suksessie af en tweedens beklemtoon hy in die besonder die opdrag om te verkondig.

... niemand kan 'n navolger van die apostels wees wat nie sy volle krag aan Christus vir die preek van die evangelie wy nie. Wie egter die amp van 'n leraar (= teoloog - VEd'A) nie vervul nie, lieg wanneer hy homself ' $n$ apostel noem (teen Rome VEd'A); in teendeel, die priesteramp van die Nuwe Testament bestaan juis daarin om met die geestelike swaard van die Woord die mense as offer tot God te bring. (CO 45, 821)

Verder is dit opvallend - en dit is ten opsigte van hierdie onderwerp belangrik - dat Calvyn in sy uitleg van Matteus 28:19 soortgelyke begrippe gebruik as in sy uitleg van Romeine 1:5 en 16:26. Volgens hom gaan dit daaroor dat die dissipels die opdrag ontvang om die evangelie orals te verkondig en 'alle volke te lei tot gehoorsaamheid van die geloof' (Comm Matt 28, 19 - CO 45, 821). Die ooreenkoms van hierdie oordeel met die laaste sin uit sy Romeinekommentaar is heel duidelik. Calvyn gebruik hierdie sentrale sendinguitspraak van Paulus ook in sy kommentaar oor Matteus 28:19, wat teologies vooruitgryp na die laaste opdrag in dieselfde vers (Matt 28:20): '... en leer hulle om alles te onderhou wat ek julle beveel het', om hulle te lei 'tot gehoorsaamheid van die geloof'. Dieselfde Pauliniese motief wat Calvyn dus in hierdie uitleg vermeld ('gehoorsaamheid van die geloof'), spruit nie slegs uit Romeine 1:5 en 16:26 nie, maar word ook in Romeine

24.Klassiek is eintlik in hierdie geval ' $n$ moderne siening vanuit die negentiendeen twintigste-eeuse sendingbeweging. In die tyd van die Reformasie is meer gedifferensieerd met die verskillende tekste waarin die opdrag is om die evangelie te verkondig, omgegaan. Dit is nie slegs tot die volgende enkele tekste beperk nie: Matteus 28:19: 'Gaan dan heen, maak dissipels van al die nasies, en doop hulle in die Naam van die Vader en die Seun en die Heilige Gees; en leer hulle om alles te onderhou wat ek julle beveel het.'

Markus 16:15: 'En Hy het vir hulle gesê: Gaan die hele wêreld in en verkondig die evangelie aan die ganse mensdom.'

25.Vergelyk Calvyn se 1555-kommentaar op Matteus 28:18 e.v. (CO 45, 821) as deel van sy kommentaar op die sinoptiese evangelies -16 jaar ná die eerste uitgawe en net ' $n$ jaar voor die derde en laaste uitgawe van sy Romeinekommentaar.
10:16 vermeld. Die opvallende is dat Calvyn in sy uitleg van Matteus 28:19 'n formulering uit die Romeinebrief gebruik. En die merkwaardige van Romeine 10:16 - direk vóór die buitengewoon belangrike vers vir die Reformasie - (Rom 10:17: 'Die geloof is dus uit die gehoor en die gehoor is deur die Woord van God') - is dat daar binne die konteks van Woordbediening negatief daaroor gepraat word dat 'hulle ... nie almal gehoorsaam [was] aan die evangelie nie'. Teologies vind ons gevolglik binne die samehang tussen Romeine 1:5, 10:16-17 en 16:26 al die sleutelbegrippe waaroor dit vir Calvyn in sy sendingbeskouing gaan, naamlik prediking, geloof en gehoorsaamheid.

Hoebelangrik hierdie teks (Rom 10) vir die sendingbeskouing van Calvyn en vir 'n gereformeerde begronding vir die sending is, word duidelik uit Calvyn se uitleg van Romeine 10:15:

Hy gee te kenne dat dit ' $n$ bewys en pand van die goddelike liefde is wanneer Hy enige volk met die prediking van die evangelie begunstig, en dat daar nie enige verkondiger daarvan is wat Hy nie deur sy besondere voorsienigheid verwek het nie. Daarom ly dit geen twyfel nie, dat God daardie volk besoek in wie se midde die evangelie verkondig word. ... Laat dit genoegsaam wees om dit in gedagte te hou, dat die evangelie nie by toeval uit die wolke neerval nie, maar dat dit deur die hand van mense gebring word na waar dit van Godsweë gestuur is. (COR II/XIII, 199:26 e.v.; Afrikaans in Calvyn [1556] 2008:263-264)

In Romeine 10:15 is sprake van predikers 'wat gestuur word', met ander woorde van sendelinge. In die sentrum staan die prediking, die mondelinge verkondiging. Die vergelyking - byna in die vorm van trappe van vergelyking - is by Paulus duidelik. Dit word deur Calvyn oorgeneem en aan die einde van die kommentaar kom die finale konklusie:

Die doel van die verkondiging van die evangelie, waaraan hy [Paulus] herinner het aan die begin van die eerste hoofstuk, vermeld hy weer, naamlik sodat God al die heidene [volke] byeenbring in gehoorsaamheid van die geloof. (COR II/XIII, 317, 14-16; vir Afrikaans, vgl. Calvyn [1556] 2008:367)

Wat van besondere betekenis in die slot van Calvyn se Romeinekommentaar is, is dat ' $n$ mens volgens hom in die woorde van Paulus die stem van die goeie Herder hoor asook die opdrag wat hy aan sy apostels gegee het: ... gaan dan heen, maak dissipels van al die nasies ... (Matt 28:19).

Sy kommentaar op die Romeinebrief bied egter 'n sleutel tot sy sendingbeskouing, veral Romeine 10:17 (binne die raam van die reeds genoemde Rom 1:5 en 16:26): Die geloof is dus uit die gehoor en die gehoor is deur die Woord van God.

Vir die Woordteoloog, Calvyn, gaan dit in die eerste en in die laaste plek oor die bediening van die Woord. Terwyl dit nie sonder deeglike historiese begronding is om te sê dat die ampsbeskrywing 'bedienaar van die Woord van God' die mees treffende sou wees om enigsins Calvyn se lewenswerk mee te beskryf nie (hy het jare 
lank 'n gemiddeld van vyf of meer nuwe preke per week gehandhaaf), durf ons nie nalaat om in een asem met sy groot werk as prediker na hom ook as sendeling te verwys nie. Sy klem op sendingwerk en die Here se eis in hierdie verband kan nie genoegsaam uitgelig word nie. Uit Calvyn se Woord-van-God-teologie kan aangetoon word dat alle Skrifuitleg, ja alle teologiese werksaamheid ook op sendingwerk gerig moet wees.

\section{Slot}

Het Calvyn in sy teologie enigsins oor sending gereflekteer? Het hy 500 jaar ná sy geboorte nog iets oor sending te sê en indien wel, wat? Wat was sy sendingbeskouing?

Die sleutel tot hierdie vrae lê in die eerste instansie by sy siening van die Woordverkondiging. Volgens hom het nie slegs die apostels die opdrag tot sending gehad nie die opdrag tot die uitdra van die evangelie - maar alle gelowiges, alle kinders van die Here was hierby inbegrepe dus ook alle gelowige teoloë. Sonder om bepaalde sogenaamde sendingtekste as dicta probantia aan te wend, het Calvyn hulle en ook ander Skrifgedeeltes gedifferensieerd uitgelê. Wanneer teologies byvoorbeeld vanuit die hoek van Calvyn se Romeinekommentaar op die vraag wat sy siening met betrekking tot die verhouding tussen die teologie en die sending was, ingegaan word, kan verskillende gevolgtrekkings samevattend gemaak word.

Juis Calvyn se uiteensetting van die bybelse uitverkiesingsleer toon aan dat sendingwerk noodwendig, ja noodsaaklik is en dat dit tot die wese van nie net kerkwees nie, maar ook gelowig wees behoort. Die sendingopdrag word deur Calvyn Christologies-ekklesiologies met sy begrip van die Ryk van God direk op die Skrif begrond. 'n Kerk is slegs kerk wanneer dit missionêr (sending-)gerig is; met ander woorde wanneer die Woordverkondiging sentraal staan, nie net na binne nie, maar ook na buite. Wesenlik vir hierdie gevolgtrekking is egter dat Calvyn veral die plaaslike, sigbare kerk (gemeente) in die blikveld het.

Sending as die uitdra van die evangelie onder die ongelowiges is die opdrag aan die gemeente, die predikant sowel as alle lidmate. In hierdie sin is dit vir Calvyn vanselfsprekend dat alle teoloë die sendingopdrag ontvang het. 'n Skeiding tussen teologie as wetenskap en die bediening van die Woord, tussen akademie en Woordbediening soos wat dit toenemend in Suid-Afrika waargeneem word, kan 'n mens nie by hom vind nie. Volgens Calvyn is die belangrikste opgawe van 'n teoloog dié van verkondiging - verkondiging deur 'n deeglike, begronde eksegese in die geloof. Dit sluit die onderskeie teologiese gebiede in (bibliologiese, dogmatiese, historiese, praktiese teologie). Volgens Calvyn is die teologie 'n eenheid. Die teologiese opgawe is uiteindelik op die prediking, die verkondiging van die Woord, gerig. En die objek van hierdie handeling, die ontvangers of adressate van hierdie verkondiging, is die hele wêreld, alle volke, alle mense. Daarom, volgens Calvyn, is daar nog soveel werk.

\section{Erkenning Mededingende belange}

Die outeur verklaar hiermee dat hy geen finansiële of persoonlike verbintenis het met enige party wat hom nadelig of voordelig kon beïnvloed het in die skryf van hierdie artikel nie.

\section{Literatuurverwysings}

Ahn, I.-S., 2008, 'Die Rezeption Calvins in Asien', in H.J. Selderhuis (Hrsg.), Calvin Handbuch, pp. 505-511, Mohr Siebeck, Tübingen.

Anderson, G.H. (ed.), [1997] 1999, Biographical dictionary of Christian missions, viewed 05 May 2014, from http://books.google.de/books?id=oQ8BFk9K0To C\&pg=PA111\&lpg=PA111\&dq=Calvin+Mission+Brazil\&source=bl\&ots=63ie C\&pg=PA111\&lpg=PA111\&dq=Calvin+Mission+Brazil\&source=bl\&ots= $=63 i \mathrm{ie}$
Mgwd_\&sig=EBF53ut3HktiKmNorCLjfROWpv4\&hl=de\&sa=X\&ei=KRZoU768Mgwd_\&sig=EBF53ut3HktiKmNorCLjfROWpv4\&hl=de\&sa=X\&ei=KRZoU768-
EsGAPb_BgfAD\&ved=0CDsQ6AEwAjgK\#v=onepage\& $q=$ Calvin $\% 20$ Mission $\% 20$ Brazil\& $\mathrm{f}=\mathrm{false}$

Anon., 1957, 'Missions', in F.L. Cross (ed.), The Oxford dictionary of the Christian church, pp. 907-908, Oxford University Press, New York.

Anon., 1974, 'Missions' in F.L. Cross \& E.A. Livingstone (eds.), The Oxford dictionary of the Christian church, p. 923, Oxford University Press, New York.

Anon., 1997, 'Missions' in F.L. Cross \& E.A. Livingstone (eds.), The Oxford dictionary of the Christian church, p. 1101, Oxford University Press, New York.

Barrett, C.K., 1991, 'Paulus als Missionar und Theologe', in M. Hengel (Hrsg.), Paulus und das antike Judentum: Tübingen-Durham-Symposium im Gedenken an den 50. Todestag Adolf Schlatters (19. Mai 1938), pp. 1-16, Mohr Siebeck, Tübingen.

Barth, K., 1932, 'Die Theologie und die Mission in der Gegenwart', Zwischen den Zeiten 10(3), 189-215.

Barth, K., 1959, Kirchliche Dogmatik (KD), IV, 3, 2, Theologischer Verlag, Zürich.

Beaver, R.P., 1967, 'The Genevan mission to Brazil', Reformed Journal 17, 14-20.

Beeke, J.R., 2004, 'Calvin's evangelism', Mid-America Journal of Theology 15, 67-86.

Blacketer, R.A., 2008, 'Kommentare und Vorreden', in H.J. Selderhuis (Hrsg.), Calvin Handbuch, pp. 179-190, Mohr Siebeck, Tübingen.

Bosch, D.J., 1979, Heil vir die wêreld: Die Christelike sending in teologiese perspektief, N.G. Kerkboekhandel, Pretoria.

Britz, R.M. \& D'Assonville, V.E., 2008, 'Die Rezeption Calvins in Afrika', in H.J. Selderhuis (Hrsg.), Calvin Handbuch, pp. 498-504, Mohr Siebeck, Tübingen.

Calvin, J. [1531-1564] 1863-1900, 'loannis Calvini opera quae supersunt omnia', (ediderunt) G[W]. Baum, E. Cunitz \& E. Reuss, Vol. I-LIX in Corpus Reformatorum, Vol. XXIX-LXXXVII, C.A. Schwetschke \& filium, Brunsvigae. [= CO 1-59].

Calvin, J. [1540, 1551, 1556] 1999, 'Commentarius in epistolam Pauli ad Romanos', (ediderunt) T.H.L. Parker \& D.C. Parker in Auspiciis Praesidii Conventus Internationalis Studiis Calvinianis Fovendis ediderunt B.G. Armstrong, C. Augustijn, I. Backus, O. Fatio, H. Feld, F.M. Higman, W.H. Neuser, B. Roussel, W. van 't Spijker \& D.F. Wright, loannis Calvini opera omnia: Denuo recognita et adnotatione critica instructa notisque illustrata, Droz, Genève. (Series II: Opera exegetica Veteris et Novi Testamenti, Vol. XIII) [= COR II/XIII.]

Calvyn, J. [1556] 2008, Kommentaar op Romeine, vert. S. Postma, Calvyn Jubileum Boekefonds, Potchefstroom. (UFS Theological Studies: Classical Texts, 1)

CO [= Calvini opera omnia, in Corpus Reformatorum], see Calvin, J. [1531-1564] 1863-1900.

COR [= Calvini opera recognita], see Calvin, J. [1540, 1551, 1556] 1999.

Dankbaar, W.F., 1978, Hervormers en humanisten: Een bundel opstellen, Ton Bolland, Amsterdam.

D’Assonville, V.E., 2001, Der Begriff 'doctrina' bei Johannes Calvin - eine theologische Analyse, LIT Verlag, Münster

D'Assonville, V.E., 2008, 'Exegese und Doctrina', in H.J. Selderhuis (Hrsg.), Calvin Handbuch, pp. 372-378, Mohr Siebeck, Tübingen.

Gensichen, D.H.-W., c.1960, 'Were the reformers indifferent to mission?' in History's lessons for tomorrow's mission, p. 119-127, World Student Christian Federation, Geneva.

Haykin, M.A.G., 2009, 'A sacrifice well pleasing to God': John Calvin and the missionary endeavor of the church, viewed 05 May 2014, from http://www. andrewfullercenter.org/files/john-calvin-on-missions-article.pdf

Knak, S., 1932, 'Die Theologie und die Mission in der Gegenwart: Eine Antwort an Karl Barth', Zwischen den Zeiten 10(4), 331-355.

Kollbrunner, F., 1988, 'Mission', in V. Drehsen, H. Häring, K.-J. Kuschel, H. Siemers \& M. Baumotte (Hrsg.), Wörterbuch des Christentums, pp. 811-814, Gütersloher Verlagshaus Gerd Mohn, Gütersloh.

Labuschagne, J.P., 2009, 'Calvin and mission', HTS Teologiese/Theological Studies 65(1), Art. \#310, 8 pages. http://dx.doi.org/10.4102/hts.v65i1.310

Lange van Ravenswaay, J.M.J., 2008, 'Calvin und die Juden', in H.J. Selderhuis (Hrsg.), Calvin Handbuch, pp. 143-146, Mohr Siebeck, Tübingen.

Manetsch, S.M., 2008, 'Die Rezeption Calvins in Amerika', in H.J. Selderhuis (Hrsg.), Calvin Handbuch, pp. 511-519, Mohr Siebeck, Tübingen. 
McGrath, A.E., 1990, A life of John Calvin: A study in the shaping of Western culture, Blackwell, Oxford.

McGrath, A.E., 2008, Christianity's dangerous idea: The protestant revolution $A$ history from the sixteenth century to the twenty-first, HarperCollins, New York.

McKay, D., 2008, 'The missionary zeal of Calvin', Lux Mundi 27(4), December, 83-89.

Mentzer, R.A., 2008, 'Calvin und Frankreich', in H.J. Selderhuis (Hrsg.), Calvin Handbuch, pp. 78-87, Mohr Siebeck, Tübingen.

Mereweather-Thompson, C., 2010, 'The challenge to mission and dialogue in a pluralist context', PhD thesis, Faculty of Theology, NWU, Potchefstroom Campus in association with Greenwich School of Theology, Potchefstroom.

Morecraft, J. III, 2010, 'John Calvin: Evangelism and world missions', Counsel of Chalcedon (2), 4-11.

Naphy, W.G., 2008, 'Calvins zweiter Aufenthalt in Genf', in H.J. Selderhuis (Hrsg.), Calvin Handbuch, pp. 44-57, Mohr Siebeck, Tübingen.

Neuser, W.H., 2008, 'Frankreich und Basel', in H.J. Selderhuis (Hrsg.), Calvin Handbuch, pp. 24-30, Mohr Siebeck, Tübingen.

Neuser, W.H., 2009, Johann Calvin: Leben und Werk in seiner Frühzeit 1509-1541, Vandenhoeck \& Ruprecht, Göttingen.

Park, G.S., 2009, 'Calvin's reformation and mission', Mission and Theology 24, 97-129, viewed 31 January 2010, from http://www.earticle.net/ FileArticle/200803/633421354792500000.pdf

Parker, T.H.L. \& Parker, D.C., 1999, 'Introduction', in COR II/XIII, pp. XI-LXXXII.

Pfisterer, E., 1934, 'Der Missionsgedanke bei Kalvin', Neue Allgemeine Missionszeitschrift, 93-108.

Pogson, M., 1990, 'Calvin's missionary thought and practice', Banner of Truth 318 March, 15-17.

Schirrmacher, T. (ed.), 2009, Calvin and world mission, Verlag für Theologie und Religionswissenschaft (VTR), Hamburg.

Schlatter, A., 1934, Paulus, der Bote Jesu, Calwer Verlag, Stuttgart.
Schlatter, W., 1909, 'Kalvin und die Mission', Evangelisches Missions-Magazin 53(8), 333-343.

Selderhuis, H.J. (Hrsg.), 2008a, Calvin Handbuch, Mohr Siebeck, Tübingen.

Selderhuis, H.J. (red.), 2008b, Calvijn Handboek, Kok, Kampen.

Selderhuis, H.J., 2008c, 'Institutio', in H.J. Selderhuis (Hrsg.), Calvin Handbuch, pp. 197-204, Mohr Siebeck, Tübingen.

Selderhuis, H.J. (ed.), 2009, The Calvin Handbook, Eerdmans, Grand Rapids.

Thomas, D., 2009, 'Calvin and missions', Puritan Reformed Journal 1(2), July, 212-217.

Van de Beek, A., 2012, Lichaam en Geest van Christus - De theologie van de kerk en de Heilige Geest, Meinema, Zoetermeer.

Van den Berg, J., 1950, 'Calvin's missionary message: Some remarks about the relation between Calvinism and missions', The Evangelical Quarterly, July, 174-187.

Vorgrimler, H., 2000, Neues Theologisches Wörterbuch (mit CD-ROM), Herder, Freiburg im Breisgau.

Warneck, D.G., 1901, Abriß einer Geschichte der protestantischen Mission von der Reformation bis auf die Gegenwart: Ein Beitrag zur neueren Kirchengeschichte, 7 , Ausgabe, Verlag von Martin Warneck, Berlin.

Wentsel, B., 1981, Het Woord, de Zoon en de dienst, Kok, Kampen. (Dogmatiek, 1)

Wierda, S.J., 2001, Visie op de gemeente, Theologische Universiteit, Apeldoorn. (Apeldoornse Studies no. 42)

Wilcox, P.J., 1993, 'Restoration, Reformation and the progress of the kingdom of Christ: Evangelisation in the thought and practice of John Calvin, 1555-1564', DPhil Thesis, Faculty of Theology, University of Oxford, Oxford.

Wilcox, P.J., 1995, 'Evangelisation in the thought and practice of John Calvin', Anvil: An Anglican Evangelical Journal for Theology and Mission 12(3), 201-217.

Zwemer, S.M., 1950, 'Calvinism and the missionary enterprise', Theology Today, 206-216. http://dx.doi.org/10.1177/004057365000700208 